COMPETITOR: Jurnal Pendidikan Kepelatihan Olahraga

Volume 13 Number 1 Year 2021

e-ISSN: 2657-0734 \& p-ISSN: 2085-5389

This work is licensed under a Creative Commons Attribution 4.0 International License

\title{
The Relationship between Sports Facility Service Quality and Customer Satisfaction of GOR Saparua
}

\author{
Muhamad Rachmaan Kurniawan ${ }^{1^{*}}$, Yudha Munajat Saputra ${ }^{2}$, Nurlan Kusmaedi ${ }^{3}$ \\ ${ }_{1,2,3}$ Postgraduate Program/Indonesian Education University/West Java/Indonesia \\ 1,2,3 J1. Dr. Setiabudhi No.229, Isola, Kec. Sukasari, Bandung City, West Java, 40154 \\ 1mrachmaan@gmail.com, ${ }^{2}$ yudhamsaputra@upi.edu, ${ }^{3}$ nurlankusmaedi11@gmail.com
}

Received: December 24, 2020; Reviewed: December 27, 2020; Accepted: January 08, 2021; Published: February 27, 2021

\begin{abstract}
Public service is a government obligation in fulfilling the rights of every citizen. To facilitate the delivery of government services to the community, a public service model is needed. One of them in public service is sports. Of course, sports play an important role in the development of human life. Public sports facilities have played a very important role in promoting physical activity and participation in recreational sports activities. Therefore, there are significant efforts to continuously improve the image of recreational sports and to pursue the improvement of the service quality of public sports facilities. Several dimensions can be measured to determine service quality on customer satisfaction, including tangibility, reliability, assurance, responsiveness, and empathy. This study aims to determine whether there is a relationship between service quality and customer satisfaction who visits Saparua Sports Hall, Bandung City. This type of research is correlational and the method used is quantitative with an accidental sampling technique with a sample size of 100 respondents. The overall result of the study is that there is a relationship between service quality and customer satisfaction who visits Saparua Sports Hall.
\end{abstract}

Keywords: Public Facilities; Sports; Quality of Service; Customer Satisfaction.

\section{INTRODUCTION}

Individual humans cannot create all goods or services to meet their various needs. Therefore, in his life, humans have various roles to play. In fulfilling their needs, humans need services, both from themselves and through the work of others. Service is the process of meeting needs directly through other people's activities. Quality is the suitability of using a product to meet customer needs and satisfaction according to Philip B. Crosby in Witara (2015). Service quality is a focused evaluation that reflects the perceptions of the dimensions of the service itself, namely tangible, reliability, assurance, responsiveness, and empathy. The effect that is given by each consumer who gets a positive value from what he gets. Usually, these consumers will come back when visiting a place, buy back a product. This situation is commonly 
The Relationship between Sports Facility Service Quality and Customer Satisfaction of GOR Saparua

Muhamad Rachmaan Kurniawan ${ }^{1 *}$, Yudha Munajat Saputra ${ }^{2}$, Nurlan Kusmaedi ${ }^{3}$

${ }^{1}$ mrachmaan@gmail.com,

known as a change in a person's behavior towards an object that is purchased or sought (P. Kotler \& Keller, 2009). In modern times, sports must be one of the human needs not only for physical and spiritual fitness but also useful for supporting our daily activities. As (Mahendra, 2007) that sports are very meaningful as the best vehicle for developing humans from the aspects of fitness and health, discipline, honesty, tolerance, mutual respect, moral and emotional health, and various life skills. Public sports facilities have played a very important role in promoting physical activity and participation in recreational sports activities. Therefore, there are significant efforts to continuously improve the image of recreational sports and to pursue the improvement of the service quality of public sports facilities. Several studies report that many public sports facilities operated by national or local governments are mismanaged due to a lack of user-centered operational management. Hence, many public sports facilities have low participation rates due to their failure to provide good quality services. Finally, the level of satisfaction with the service quality of a public sports facility has the characteristic that the environment, processes, people, services, and products are determined through their dynamic interplay. Saparua Sports Hall is divided into two parts, namely indoor and outdoor. The indoor part is the main building of the Saparua Sports Hall which is usually used for martial arts and volleyball sports activities. The outdoor part consists of a jogging track, basketball court, roller skating track, rock climbing, and also a garden. The high public interest in exercising at Saparua Sports Hall needs the best public sports facilities services. The services provided have a very positive impact on consumers and are an advantage that is owned by individuals or businesses in the service and trade sector (Tjiptono \& Chandra, 2005). Oh (2001) conducted a study on the effect of service quality public sports facilities on consumer satisfaction, repurchase intention, and word of mouth intention. Jang \& Bae (2003) conducted a study on the relationship between sports center service quality and customer satisfaction. Also, studies on the influence of service quality in public sports centers regarding the intention of the word of mouth and intention to revisit were conducted (Kim \& Yun, 2004; Jeong, Kim \& Kwon, 2004).

\section{METHOD}

This research uses quantitative methods, which can be interpreted as a research 
The Relationship between Sports Facility Service Quality and Customer Satisfaction of GOR Saparua

Muhamad Rachmaan Kurniawan ${ }^{1^{*}}$, Yudha Munajat Saputra ${ }^{2,}$, Nurlan Kusmaedi ${ }^{3}$

1mrachmaan@gmail.com,

method based on the philosophy of positivism, used to study a specific population or sample, data collection using research instruments, quantitative or statistical data analysis, to test predetermined hypotheses. (Sugiyono, 2012). The approach used is the approach with survey method, the survey method is a method used to obtain data from certain natural (not artificial) places, but the researcher treats data collection, for example by distributing questionnaires, tests, structured interviews, and so on. (Sugiyono, 2009). This research uses a correlational approach. This method aims to examine the extent to which variations in a factor are related to other factors. This study, this study aims to determine whether there is a relationship between one variable and another, which includes the analysis of the relationship between the quality of sports facilities services (X) and the customer satisfaction of GOR Saparua (Y) through hypothesis testing. (Sugiyono, 2012: 30) This research was conducted at GOR Saparua in 2020. With accidental samples, where the technique of determining the sample based on chance, namely consumers who accidentally / incidentally meet the researcher can be used as a sample if it is considered that the person who happened to be met is suitable as a data source. The results of this study only describe or construct semistructured questionnaires, participant observations, and questionnaires on research subjects so that they can provide a clear picture of the quality of sports facilities services with GOR Saparua customer satisfaction.

\section{RESULTS AND DISCUSSION}

Data collected through a measurement process then processed and analyzed using a statistical approach. The data from this research were obtained from the results of the questionnaire value on the quality of sports facilities services with GOR Saparua customer satisfaction.

Table 1.

Descriptive Statistic

\begin{tabular}{cccccc} 
& N & Minimum & Maximum & Mean & Std.Deviation \\
\hline Layanan & 100 & 44 & 100 & 84.41 & 11.247 \\
Kepuasan & 100 & 14 & 24 & 20.21 & 2.815 \\
\hline Valid N (listwise) & $\mathbf{1 0 0}$ & & & & \\
\hline
\end{tabular}




\section{Tabel 2}

One-Sample Kolmogorov-Smirnov Test

\begin{tabular}{llr}
\hline & & Unstandardized Residual \\
\hline Normal Parameters & & 100 \\
& & .0000000 \\
Most Extreme Differences & Sean & 2.25835918 \\
& Absolute & .095 \\
& Positive & .066 \\
Test Statistic & Negative & -.095 \\
Asymp. Sig. (2-tailed) & & .095 \\
\hline
\end{tabular}

a. Test distribution is Normal.

b. Calculated from data.

c. Lilliefors Significance Correction.

\section{Tabel 3}

Correlations

\begin{tabular}{llrr}
\hline & & Layanan & Kepuasan \\
\hline Layanan & Pearson Correlation & 1 & $.597^{* *}$ \\
& Sig. (2-tailed) & & .000 \\
& $\mathrm{~N}$ & 100 & 100 \\
Kepuasan & Pearson Correlation & $.597^{\star *}$ & 1 \\
& Sig. (2-tailed) & .000 & 100 \\
\hline \multirow{2}{*}{ N. Correlation is significant at the 0.01 level (2-tailed). } & 100 &
\end{tabular}

Data collected through a measurement process then processed and analyzed using a statistical approach. Based on a questionnaire that has been distributed to consumers, shows that service quality indicators are very important to achieve goals. This illustrates that most of the managers have performed their service quite well. Where the management pays attention to service to consumers so that every consumer feels satisfied and gets comfort at every visit. After processing and analyzing data, the results of the data analysis above prove that there is a significant relationship between the level of customer satisfaction and the service quality of the Saparua sports facilities. With this, the correlation value between the level of customer satisfaction and the quality of sports facilities service is 0.597 which indicates that there is a strong enough relationship between the level of customer satisfaction and the quality of sports facilities services at GOR Saparua. 


\section{CONCLUSIONS AND SUGGESTIONS}

From the results of the research that has been carried out by researchers, it can be concluded that the main focus of this study is that the researcher wants to know and see the relationship between the quality of sports facilities services and customer satisfaction of GOR Saparua to improve the quality of service quality sports facilities in the city of Bandung, especially in Indonesia, and be a reference or barometer for better sports policy going forward.

\section{REFERENCES}

Jang, Kyung-Ro \& Bae, Hyang-Nam (2003). A study on the service quality of sport-forall centers and consumer satisfaction. Journal of the Korean Society of Sport and Leisure Studies, 19(1), 539-550.

Kim, Hak-Sin \& Yun, Tae-Hoon (2004). The Management Plan According to the Type of Residents' Satisfaction With Public Sports Facilities. Journal of the Korean Society of Sport and Leisure Studies, 21(1). 303-312.

Kotler, P., \& Keller, K. L. (2009). Marketing Management (13th ed.). In Prentice Hall

Oh, Hyun-Hwan (2001). The effect of the service quality of public sports facilities on consumer satisfaction, Repurchase Intention and Word-of-mouth Intention. Joumal of KAHPERD,

Sugiyono 2009. Metode Penelitian Kuantitatif Kualitatif Dan R\&D. Bandung: Alfabeta

Sugiyono. 2012. Metode Penelitian Kuantitatif Kualitatif dan R\&D. Bandung:CV. Alfabeta

Tjiptono, F., \& Chandra, G. (2005). Manajemen Kualitas Jasa. Yogyakarta. ANDI. https://doi.org/10.12691/jbms-4-4-1

Witara, Ketut (2018). Cara Singkat Memahami Sistem Manajemen Mutu ISO 9001:2015 dan Implementasinya: Sukabumi. CV. Jejak 